УДК 351.746.1(477)

DOI https://doi.org/10.32837/apdp.v0i90.3211

Ю. Б. Курилюк

\title{
ЗНАЧЕННЯ ДЕРЖАВНОГО КОРДОНУ ДЛЯ ЗАБЕЗПЕЧЕННЯ ПРАВОПОРЯДКУ В УКРАЇНІ
}

Постановка проблеми. Після проголошення 1991 року своєї незалежності перед молодою Українською державою постало складне та надважливе питання щодо формування і встановлення свого державного кордону, визначення порядку його охорони і проходження, а також утворення спеціально уповноваженої державної прикордонної інституції.

Маючи за необхідне охороняти території України у межах існуючих кордонів відповідно до принципів їх непорушності та недоторканності, що є відображенням територіальної цілісності, політичної та економічної незалежності, суверенітету та єдності України, ï̈ національної безпеки, в першу чергу державою схвалені Закони України «Про державний кордон України» i «Про Прикордонні війська України» (04.11.1991), чим підкреслюється особлива роль державної функції з охорони державного кордону України [1, с. 3].

Аналіз останніх досліджень і публікацій. Загалом до головних завдань державного кордону науковці (В. Березенко, Ю. Дем'янюк, О. Діденко, Д. Купрієнко, Т. Цимбалістий та ін.) відносять визначення просторових меж територіального верховенства держави, а також обмеження приналежної їй території, що складає матеріальну основу життєдіяльності держави та її народу, забезпеченні їх захисту [2, с. 8,$130 ; 3$, с. $41 ; 4$, с. 51 тощо]. Така позиція дослідників є не безпідставною, адже, як зауважують фахівці з теорії держави і права, найважливішими ознаками будь-якої держави прийнято вважати територію, іï населення, публічну владу у формі державної влади, суверенітет, державний апарат, право [5, с. 60]. Проте варто відзначити, що доктриною, незважаючи на актуальність, досі надто мало уваги приділено розкриттю значення, яке має державний кордон для забезпечення правопорядку в державі, а тому метою цієї статті є розкриття авторського підходу до окресленої проблеми.

Виклад основного матеріалу. Фактор кордону вважається одним із таких, що помітно впливає на індивідуальну та суспільну свідомість. Важливим чинником у формуванні уявлення про бар'єрність кордону є визнання його існування також у суб'єктивному сприйнятті людьми. Феноменологія кордону, фронтиру, межі та пов'язаних з ним явищ $є$ предметом лімології як науки про кордони. В Україні дослідження проводяться також у і межах прикордоннології як інтегральної галузі знань про кордон та супутні прикордонні явища і процеси, пов'язані із забезпеченням прикордонної безпеки [6, с. 77].

Зокрема, лімологією під кордоном розуміється «елемент простору в його геополітичному вимірі, символ, що орієнтує політичний, економічний, правовий і культурно-інформаційний ландшафт у напрямку певного ядра й цим самим відіграє роль міцного централізуючого фактору» [7, с. 87].

(C) Ю. Б. Курилюк, 2021 
У доктрині міжнародного права державний кордон розглядають як «позначену на картах і закріплену маркуванням на місцевості лінію та вертикальну площину, що проходить по ній і визначає зовнішні межі державної території (сухопутної, водної, повітряної)» [8, с. 219], або як «лінію і уявну вертикальну поверхню, що проходить через цю лінію, визначає межі державної території - суходолу, вод, надр, повітряного простору, тобто межі розповсюдження державного суверенітету» [9, с. 742]. Схожий підхід має Т. Цимбалістий, визначивши, що державним кордоном це «встановлена юридично чи фактично штучна лінія (на суші і воді) і вертикальна поверхня, що проходить по цій лінії (в надрах, водах і повітряному просторі), які визначають просторові межі території держави і сфери здійснення нею свого суверенітету (територіального верховенства)» [10, с. 65].

Інші науковці (В. Березенко, Н. Камінська та ін.) вважають, що державний кордон - це лінія, вертикальна поверхня, що проходить усією лінією та визначена державою вздовж цієї лінії смуга її території, на якій розташовані необхідні атрибути iї впізнання, насамперед прикордонні стовпи, технічні й інші прикордонні об’єктивні знаки та споруди [3, с. $41 ; 11$, с. 23$]$.

Легальне ж поняття державного кордону, наведене у національному законодавстві України, здебільшого збігається з його доктринальними напрацюваннями. Так, ст. 1 Закону України «Про державний кордон України» встановлено, що державним кордоном $\epsilon$ «лінія і вертикальна поверхня, що проходить по цій лінії, які визначають межі території України - суші, вод, надр, повітряного простору».

Загалом, державний кордон є невід'ємним атрибутом держави й одним із головних параметрів державної території [12, с. 82], невід’ємний і обов'язковий чинник формування цілісного державно-територіального організму. Без чітко визначених кордонів держава не може реалізувати весь комплекс своїх суверенних прав. Від функціонування державного кордону залежить і розвиток міждержавних та поза державних, зокрема економічних, торгівельних, демографічних, соціальних та інших відносин [10, с. 3].

Як справедливо відзначав О. Задорожній, незалежно від того, як визначати вимоги державності, абсолютно необхідний критерій території. При цьому неодмінний атрибут держави не просто територія, а територія, окреслена кордонами, вона - найважливіший компонент суверенітету держави, адже в державно-правовому аспекті територія тісно пов'язана з суверенітетом. Принцип же виняткового суверенітету держави над своєю територією передбачає як владу держави по відношенню до території, так і те, що в інших держав нема права претендувати на цю територію [13, с. 199, 200].

Існування держав, що відокремлюють свою територію від території інших за допомогою державного кордону, пов'язане з установленням останніх, оскільки саме вони є тими межами, в яких реалізується державна влада, і тими межовими знаками території, на якій проживає ії населення. Державний кордон - це невід’ємний і обов'язковий чинник формування цілісного державно-територіального організму. Без чіткого визначення своїх кордонів держава не може повною мірою реалізувати суверенні права, якими вона наділена. Від належного функціонування державного кордону також залежить і розвиток прикордонних правовід- 
носин, у т.ч. міждержавних, оскільки саме державний кордон є тим маркером, що характеризує рівень відкритості й цивілізованості окремо взятої держави для міжнародного співробітництва. Водночас чітко визначені, усталені, а також захищені правом і надійно охоронювані кордони держави є однією з умов забезпечення безпеки будь-якої держави [4, с. 51].

Проблема державної території завжди була однією з найбільш важливіших і складних як для юридичної науки, так і наук гуманітарного циклу, природничих, технічних та інших наук, оскільки територія є не лише певним простором, але також необхідним атрибутом будь-якої держави, матеріальним підгрунтям життєдіяльності населення цієї держави та, напевно, всього людства у цілому та складових частин його існування зокрема.

Території в зоні впливу державного кордону України набувають тепер надзвичайного політичного та економічного значення [14, с. 12], а прикордонні райони за сучасних умов набувають значення «перших рубежів», які сприймаються як позитивні, так і негативні наслідки інтеграційних процесів [14, с. 39].

Ідентифікація окремо взятих людських спільнот з окресленою певними межами територією наповнює різні ї̈ частини високим і доволі символічним значенням. Як зауважує В. Владіміров, «державні кордони являють собою рубежі, що розділяють території» [14, с. 42], оскільки кордони мають властивість відмежовувати сусідні регіони та мають певне бар'єрне призначення. Кордони відгороджують мешканців відповідної території від загроз, що йдуть з-за них, які, у свою чергу, в масовій уяві мають здебільшого негативний характер. Звідси - розуміння кордону невіддільно зв’язується з поняттям державної безпеки та неминучістю задіяння для ї̈ убезпечення уповноважених державних інституцій.

Кордон споконвіку вважається природним місцем розташування прикордонних, митних та інших, здебільшого мілітаризованих, структур, покликаних забезпечувати прикордонну безпеку держави як складову частину національної безпеки. Мета діяльності таких структур полягає в тому, щоб зменшити вразливість (хаос і безладдя) неконтрольованого кордону, щоб поліпшити якість життя мешканців і законних підприємств і зменшити ризик для економічної життєздатності країни. Шлях для досягнення цього полягає в тому, що єдиний спосіб увійти до України - це через законні канали, а ті, хто порушує законодавство про державний кордон, обов'язково був за це покараний.

Територіальне верховенство означає повну та виключну владу держави в межах власної території. Ця влада здійснюється цілою системою державних органів. Повнота державної влади в тому, що їй належить вся законодавча, виконавча та судова діяльність. Особливість державної влади полягає в тому, що над нею немає і не може бути ніякої іншої влади, а також на території держави виключається діяльність будь-якої іншої публічної влади. Державній владі підпорядковуються всі особи та організації в межах держаної території. Територіальне верховенство кожної держави має поважатися всіма іншими державами. Ніхто не може втручатися у внутрішні справи держави. У межах своїх кордонів держава встановлює певний правопорядок, який не повинен порушуватися іншими державами. Межі дії територіального суверенітету кожної держави обмежуються ï державними кор- 
донами [2, с. 35], а необхідною умовою нормального функціонування та належного розвитку держави і суспільства є забезпечення правопорядку [15, с. 17].

Однак варто мати на увазі, що для держави геополітичним атрибутом є не просто її територія, а певний простір, що визначається межами державного кордону, який закріплений нормами як національного, так міжнародного законодавства [16, с. 93]. Саме державний кордон визначає межі правопорядку, встановленого державою на своїй території, і ніхто, будь о приватні чи посадові особи, не мають права вступити на цю територію без дозволу компетентних органів [17, с. 49] і в порядку, що врегульований внутрішньодержавним законодавством цієї країни. О. Чуваков справедливо відзначає, що наявність державних кордонів служить не тільки протидії зовнішньому вторгненню, а також сприяє мирним партнерським взаєминам із суміжними, сусідніми державами. Відсутність таких кордонів, навпроти, провокує між подібними державами непередбачені прикордонні конфлікти тощо. Так стає необхідним прискорення процесу делімітації і демаркації державних кордонів України, що в остаточному підсумку має відбитися на продуктивності протидії організованим злочинним угрупованням, серед яких особливе місце посідають міжнародні злочинні організації, діяльність яких здійснюється незаконним проникненням на територію України [18, с. 50].

А. Крижановський зазначає, що «правопорядок завжди пов'язаний ыз певною людською спільнотою і легалізованою в ній суверенною владою, які існують на певному територіальному просторі в межах визнаних державних кордонів, а тому підставою для вирізнення національного правопорядку є організована в рамках суверенної держави та їі суспільно-просторового буття людська спільнота, яка здійснює свою життєдіяльність на основі права і створює для забезпечення у своєму суспільно-територіальному середовищі відповідні владні інституції для забезпечення правопорядку» [19, с. 61].

I. Кузнєцов справедливо звертає увагу на те, що правопорядок, а відповідно, і необхідність щодо його забезпечення та охорони є умовою існування будь-якого організованого суспільства у державі. Держава - структурна частина суспільства, яка, охороняючи це суспільство і здійснюючи забезпечення його життєдіяльність, одночасно оберігає підгрунтя і для свого власного існування [20, с. 21]. О. Черданцев відзначив, що «функція охорони правопорядку є однією з основних функцій держави, яка виникає одночасно із виникненням держави, оскільки у суспільстві $€$ неодмінною умовою нормального існування і розвитку як суспільства в цілому, так і самої держави» [21, с. 115]. Г. Туманов також дійшов висновку про те, що «однією з основних об’єктивно необхідних функцій держави є охоронна, що реалізується складною системою правозастосовних і правоохоронних органів» [22, с. 17].

Сама держава, як справедливо зауважує Г. Кельзен, є тим відносно централізованим правопорядком, який для створення й застосування правових норм засновує органи з відповідним функціональним розподілом, тобто законодавчий, адміністративний і судовий органи [23, p. 73].

Висновки. Державний кордон і правопорядок взаємозалежні категорії. Державний кордон є першоосновою та цінністю правопорядку будь-якої держави, адже без існування чітко окреслених і нормативно-врегульованих меж свого суве- 
ренітету держава, як основний суб'єкт забезпечення правопорядку, не спроможна окреслити і межі того простору, в якому діятимуть установлені нею правові норми й уповноважені державні органи охорони правопорядку. Відсутність державних кордонів утворює передумови для його руйнування як зовні - шляхом безперешкодного потрапляння на територію держави тих негативних явищ, що чинять безпосередній вплив на упорядковані внутрішньодержавні відносини (наприклад, нелегальна міграція, контрабанда наркотичних засобів тощо), так і зсередини через безперешкодне незаконне переміщення позитивних внутрішньодержавних надбань суспільства поза межі держави (наприклад, контрабанда культурних цінностей тощо) [24, с. 17].

При цьому відсутність належного правопорядку чинить безпосередній негативний вплив на ефективність системи охорони державного кордону, призводить до нехтування правовими основами прикордонної безпеки держави, постійних незаконних перетинань державного кордону чи руйнування інших упорядкованих внутрішньодержавних відносин у прикордонній сфері, аж до «перетворення правопорядку в антипорядок та гібридизації права, за якої принцип доцільності поглине законність і невідворотність відповідальності» [25, с. 24].

\section{Jimepamypa}

1. Андрушко О.В., Письменний Д.П. Дізнання в органах прикордонної служби України : монографія. Одеса : Фенікс, 2009. 204 с.

2. Територія і кордони у міжнародному праві : навч. посіб. / Ю.А. Дем’янюк, О.В. Діденко, Д.А. Купрієнко та ін. Хмельницький : НАДПСУ, 2014. 232 с.

3. Березенко В.В. Правовий режим державного кордону України: конституційно-правові аспекти регулювання та захисту : дис. ... канд. юрид. наук: спец. 12.00.02. Київ, 2017. 235 с.

4. Державна територія і державний кордон : навч. посіб. / Д.А. Купрієнко, Ю.А. Дем'янюк, О.В. Діденко. Хмельницький : НАДПСУ, 2014. 256 с.

5. Машков А.Д. Теорія держави і права : підруч. Київ : Дакор, 2014. 492 с.

6. Філіппов С.О. Протидія транскордонній злочинності: глобальний контекст і реалії України : монографія. Одеса : Фенікс, 2019. 452 c.

7. Дмитриева С.И. Лимология : уч. пос. Воронеж : ИПЦ «ВГУ», 2008. 112 с.

8. Міжнародне публічне право : підручник / за ред. В.М. Репецького. 2-ге вид., стер. Київ : Знання, 2012. $437 \mathrm{c.}$

9. Енциклопедія міжнародного права / редкол.: Ю.С. Шемшученко, В.Н. Денисов (співголови) та ін. Т. 1. А-Д. Київ : Академперіодика, 2014.920 с.

10. Цимбалістий Т.О. Державний кордон України: конституційно-правовий статус : навч. посіб. Хмельницький : НАПВУ, 2000. 204 с.

11. Камінська Н.В., Клочков Б.І. Проблеми концептуального визначення поняття державних кордонів у сучасній юридичній науці. Юридичний вісник Національної академії внутрішніх справ. 2015. № 2(10). С. $16-27$.

12. Шкабаро В.М. Типологія функцій державного кордону: аналіз існуючих досліджень. Порівняльно-аналітичне право. 2017. № 5. С. 82-85.

13. Задорожній О.В. Порушення агресивною війною Російської Федерації проти України основних принципів міжнародного права. Київ : К.І.С., 2015. 712 с.

14. Транскордонні території України (проблеми розвитку) : монографія. Київ : Укрархбудінформ, 1999. $265 \mathrm{c}$.

15. Безпалова О.І. Адміністративно-правовий механізм реалізації правоохоронної функції держави : монографія. Харків : ХНУВС, 2014. 544 с.

16. Чумак В.В. Державний кордон як об'єкт адміністративно-правового регулювання. Право і безпека. 2011. № 1(38). С. 93-96.

17. Клименко Б.М. Государственные границы - проблема мира. Москва : Междунар. отнош., $1964.138 \mathrm{c}$. 
18. Чуваков О.А. Злочини проти основ національної безпеки України: проблеми кримінально-правової теорії і практики. Одеса : Фенікс, 2017. 362 с.

19. Крижановський А.Ф. Правопорядок у суспільно-правничих контекстах: спроба системного бачення. Актуальні питання рефорлування правової систели України: матер. IV Міжнар. наук.-практ. конф. (Луцьк, 1-2 червня 2007 р.). Т. 1. Луцьк : Вежа, 2007. С. 61-66.

20. Кузнецов И.А. Теория государства и права. Волгоград : ВАГС, 2005. 228 с.

21. Черданцев А.Ф. Теория государства и права. Москва : Юрайт-М, 2002. 432 с.

22. Туманов Г.А. Теоретические проблемы научной организации управления в органах внутренних дел : автореф. дис. ... д-ра юрид. наук : спец. 12.00.02. Москва, 1974. 32 с.

23. Kelsen H. The Concept of the Legal Order. American Journal of Jurisprudence. 1982. Vol. 27. No 1. P. 64-84.

24. Курилюк Ю.Б. Державний кордон і правопорядок (законодавство, теорія, практика) : монографія. Київ : ВД «Дакор», 2020. 446 с.

25. Правовий вплив на неправомірну поведінку: актуальні грані / за ред. О.В. Козаченка, Є.Л. Стрельцова. Миколаїв : Іліон, 2016. 768 с.

\section{Анотація}

Курилюк Ю. Б. Значення державного кордону для забезпечення правопорядку в Україні. - Стаття.

У статті наведено аргументи на підтримку позиції, згідно з якою державний кордон є першоосновою та цінністю правопорядку будь-якої держави, а відсутність державних кордонів утворює передумови для руйнування правопорядку як ззовні - шляхом безперешкодного поширення на територію держави тих негативних процесів, що безпосередньо впливають на упорядковані внутрішньодержавні відносини (нелегальна міграція, контрабанда наркотичних засобів тощо), так і зсередини - через безперешкодне незаконне переміщення людських ресурсів, культурних, матеріальних та інших позитивних надбань суспільства поза межі держави (контрабанда культурних цінностей, торгівля людьми тощо). Визначено, що відсутність належного правопорядку негативно позначається на ефективності системи охорони державного кордону, призводить до нехтування правовими основами прикордонної безпеки держави, постійних незаконних перетинань державного кордону чи руйнування інших упорядкованих внутрішньодержавних відносин у прикордонній сфері. Територіальне верховенство означає повну та виключну владу держави в межах власної території. Така влада здійснюється цілою системою державних органів. Саме ці органи мають зменшити вразливість (хаос і безладдя) неконтрольованого кордону, щоб поліпшити якість життя мешканців і законних підприємств і зменшити ризик для економічної життєздатності країни. Шлях для досягнення цього полягає в тому, що єдиний спосіб увійти до України - це через законні канали, а ті, хто порушує законодавство про державний кордон, обов'язково були би за це покарані. Державний кордон покликаний бути певним бар'єром для будьяких загроз жителям відповідної держави, відтак нерозривно пов'язаний із поняттям національної безпеки, що мають забезпечувати ефективні органи правопорядку відповідного державного апарату.

Ключові слова: правопорядок, прикордонна безпека, державний кордон.

\section{Summary}

Kuryliuk Yu. B. The importance of the State border for ensuring legal order in Ukraine. - Article.

The Article presents arguments in support of the position that the State border is the basis and value of the legal order of any State, and the absence of the State borders creates preconditions for the destruction of the legal order from the outside - by unimpeded spread to the territory of the State of those negative processes that directly affect regulated domestic relations (illegal migration, drug smuggling, etc.) and inside - through the unimpeded illegal transfer of the human resources, cultural, material and other positive assets of society outside the State (smuggling of cultural values, human trafficking, etc.). It is determined that the lack of the proper legal order has a negative impact on the effectiveness of the State border protection system, leads to neglect of the legal basis of the State border security, constant illegal border crossings or destruction of other regulated internal relations in the border area. The territorial supremacy means full and exclusive power of the State within its own territory. Such power is exercised by a whole system of the state bodies. Particularly these authorities have to reduce the vulnerability (chaos and disorder) of the uncontrolled border in order to improve the quality of life of the residents and legitimate businesses and reduce the risk to the country's economic viability. The way to achieve this lies in that the only way to enter Ukraine is through the legal channels and those who violate the legislation on the State border would necessarily be punished. The State border is called to be a barrier to any threats to the inhabitants of the relevant State, and is therefore inextricably linked to the concept of the national security, which must be provided by the effective legal order protection agencies of the state apparatus.

Key words: legal order, border security, State border. 